\title{
KONSEP PENDIDIKAN MORAL MENURUT AL-GAZALI DAN ÉMILE DURKHEIM
}

\author{
Ratna \\ Pascasarjana UIN Alauddin Makassar \\ Jalan Sultan Alauddin Nomor 63 Makassar \\ Email: ratnauinalauddin@yahoo.com
}

\begin{abstract}
Abstrak:
Perkembangan sains dan teknologi telah banyak memberi perubahan dalam kehidupan masyarakat. Tetapi, yang memprihatinkan adalah perubahan itu justru mendorong munculnya krisis moral. Hal ini didasarkan pada kenyataan bahwa kemajuan ilmu pengetahuan di bidang teknologi dan informasi tidak selalu sebanding dengan kemajuan di bidang moral pada masyarakat modern. Realitas kehidupan yang menggiring aktivitas pendidikan terus berjalan dan berubahubah menuntut adanya suatu akselerasi baru dalam dunia pendidikan terkhusus pendidikan moral. Oleh karena itu, konsep pendidikan moral masih perlu dikaji secara spesifik karena konsep pendidikan moral adalah hal yang sangat penting dalam dunia pendidikan. Pendidikan moral memang bukanlah persoalan baru. Banyak ahli pendidikan telah merumuskan konsep pendidikan dan menjadikan moral sebagai bagian yang tidak terpisahkan dari sistem pendidikan. Bahkan pendidikan moral harus mampu mengintegrasikan aspek-aspek spiritual dan intelektual serta aspek normativitas dan historitas (realitas). Integrasi keseluruhan aspek tersebut akan menjadi inti bagi keseimbangan aspek kognitif, (akal), afektif (iman), dan psikomotorik (amal) dalam pendidikan secara praktis.
\end{abstract}

\begin{abstract}
:
The development of science and technology has brought about many changes in society life. However, the main concern here is that the changes have caused the existence of moral crisis. This is based on the fact that the development of knowledge in the area of technology and information is not balanced with the development of moral of modern society. The reality of life that drives educational activity continuously to run and change that demand the new acceleration in educational world, especially moral education. Therefore, the concept of moral education still needs to be specifically examined because the concept of moral education is very important in educational world. Moral education is not a new problem. There are many experts that have formulated the concept of education and have taken moral as not a separated part of educational system. Even, moral education has to integrate the spiritual and intelectual aspects and also normatif and hystorical aspects (reality). The integration of all these aspects will become the core for the balance between the aspects of cognitive (mind), affective (faith), and pychomotoric (deed) in education practices.
\end{abstract}

Kata kunci:

Pendidikan, Moralitas

PENDIDIKAN menarik perhatian serius masyarakat luas di saat moralitas dipinggirkan dari sistem berperilaku dan bersikap di tengah masyarakat. Secara de jure, pendidikan meningkatkan kualitas berbagai dimensi kehidupan manusia. Namun secara de 
facto, pendidikan yang diusung seringkali menjadikan manusia kehilangan kemanusiaannya. Aksi kekerasan, korupsi, dan sederet gambaran dekadensi moral menghadirkan kerinduan untuk mendesain ulang sistem pendidikan yang berbasis moralitas. Kehidupan dan pendi-dikan bagaikan sebuah skema listrik paralel. Keduanya saling terkait satu dengan yang lain. Oleh karena itu, jika masyarakat menghendaki kehidupan yang berkualitas, isi dan proses pendidikan harus diarahkan pada pemenuhan kebutuhan tersebut.

Fenomena sosial kehidupan masyarakat cenderung memberi perhatian khusus hanya kepada hal-hal yang berorientasi materi, bukan pemekaran nyali spiritual. Akibatnya, teknologi menjauhkan manusia dari tujuan penciptaannya dan menggiring manusia kepada bentuk alienasi, ${ }^{1}$ sehingga manusia telah menjadi budak teknologi. ${ }^{2}$ Dalam hal ini, bukan lagi teknologi yang berkembang seiring dengan perkembangan dan kebutuhan manusia, namun justru sebaliknya, manusialah akhirnya yang harus menyesuaikan diri dengan teknologi.

Arus globalisasi memang tidak dapat dielakkan dan akan terus menjalar pada sendi-sendi kehidupan masyarakat modern. Persoalannya bukanlah pada bagaimana menghentikan laju globalisasi, tetapi bagaimana menumbuh-kan kesadaran dan komitmen manusia akan nilai-nilai moral, sehingga dampak negatif dari perkembangan arus globalisasi dapat dikendalikan. Oleh karena itu, dibutuhkan suatu upaya untuk mengatasi berbagai permasalahan yang terkait dengan moral dan tingkah laku masyarakat modern.

Pendidikan moral sangat penting bagi masyarakat modern dewasa ini. Dengan pendidikan, manusia dapat memahami esensi atau arti pentingnya nilai-nilai moral dan mampu mengembangkan segala potensi yang mewujudkan nilai-nilai moral tersebut dalam setiap perilaku manusia. Para pemikir dalam merumuskan konsep pendidikan moral sangat variatif. Konsep pendidikan moral para tokoh, baik Islam maupun non Islam, masih perlu untuk ditelaah sebagai bahan pertimbangan dalam merumuskan pendidikan moral yang layak untuk di terapkan pada konteks masyarakat saat ini. Demikian halnya diharapkan dapat melahirkan berbagai inovasi baru yang sesuai dan berguna bagi pendidikan Islam serta sebagai langkah preventif terhadap realitas pendidikan yang tidak humanis.

Terkait dengan hal tersebut, nama al-Gazali dan Émile Durkheim patut untuk diajukan dan dikedepankan karena daya tarik pemikiran kedua tokoh tersebut tentang pendidikan moral berangkat dari potret sosio-kultural yang berbeda sehingga konsep pendidikan moral yang mereka tawarkan berbeda pula.

Al-Gazali dan Émile Durkheim memiliki latar belakang berbeda yang memengaruhi kerangka epistemologi kedua tokoh tersebut. Al-Gazali meru-pakan seorang filosof muslim. Ia banyak menyumbangkan pemikirannya dalam bebagai disiplin ilmu yaitu ilmu akhlak, fikih, ilmu kalam, filsafat, dan tasawuf serta pendidikan. Latar belakang pemikiran al-Gazali sangat dipenga-ruhi oleh kondisi sosial politik yang terjadi pada zamannya. Corak pemikiran al-Gazali bersifat religius, idealis, sufistik, dan mistik. Berbeda dengan al-Gazal, Émile Durkheim adalah seorang filosof yang 
berlatar belakang keagamaan non-muslim. Émile Durkheim juga seorang professor dalam bidang sosiologi dan pendidikan. Kerangka epistemologi Émile Durkheim banyak dipengaruhi oleh konteks sosial politik di Prancis yang berefek pada kemerosotan moral. Pemikiran Émile Durkheim bercorak sosial, rasional, dan empirik.

Berdasarkan uraian tersebut, tulisan ini mencoba mengkaji dan mengom-parasikan gagasan konsep pendidikan moral menurut al-Gazali dan Émile Durkheim karena kedua tokoh tersebut memiliki pengaruh yang besar terha-dap pendidikan masa kini, sehingga dapat memberikan solusi bagi pendidi-kan Islam maupun pendidikan secara umum.

Dalam pembahasan selanjutnya akan dikemukakan: pertama, perbedaan dan persamaan konsep pendidikan moral menurut al-Gazali dan Émile Durkheim. Kedua, analisis kritis terhadapa konsep pendidikan moral menurut al-Gazali dan Émile Durkheim dan relevansinya dengan konsep pendidikan Islam. Ketiga, integrasi paradigma al-Gazali dan Émile Durkheim dalam pengembangan konsep pendidikan moral pada konteks masa kini.

\section{PEMBAHASAN}

Al-Gazali dan Émile Durkheim memiliki perbedaan pandangan tentang konsep pendidikan moral. Latar belakang sosial politik yang mengitari kedua-nya adalah salah satu faktor yang mempengaruhinya. Pendidikan moral dalam pandangan alGazali bernuansa religius dan sufistik. Konsep ini jelas terlihat dari pandangannya tentang moral. Hakikat pendidikan moral al-Gazali menekankan pada aspek kejiwaan individu. Bagi al-Gazali, tujuan hidup manusia sebagai individu adalah untuk mencari kebahagiaan. Kebahagian yang paling penting adalah merealisasikan kebahagiaan di kehidupan yang akan datang atau kehidupan akhirat. Pencapaian tujuan ini dapat dicapai melalui perilaku yang baik sesama manusia berdasarkan tuntunan agama, serta mengupayakan secara batin untuk mencapai keutamaan jiwa. ${ }^{3}$ Tujuan pendidikan moral bagi al-Gazali adalah mempro-duksi manusia sempurna yang memiliki kepribadian yang baik, kesucian jiwa dan mendekatkan diri kepada Allah swt. ${ }^{4}$ Amin Abdullah mengungkapkan bahwa al-Gazali menempatkan wahyu sebagai petunjuk utama atau bahkan cenderung satu-satunya dalam tindakan etis, dan dengan keras menghindari intervensi rasio dalam merumuskan prinsip-prinsip dasar universal tentang petunjuk al-Qur'an bagi kehidupan manusia. ${ }^{5}$ Dengan demikian, sumber pendidikan moral menurut al-Gazali adalah wahyu al-Qur'an sebagai otoritas utama dalam pembentukan moral. Adapun peran rasio (akal) hanya sebagai sumber pendukung dalam tindakan etis-manusia. Dalam hal ini, rasio (akal) berperan memberikan keseimbangan dan rohani yang bersih kepada seseo-rang sehingga melahirkan moral yang baik.

Pendapat al-Gazali tersebut juga diperkuat dengan sebuah hadis yang menyebutkan bahwa sewaktu hendak mengutus Muaz bin Jabal ke negeri Yaman sebagai qadi (hakim Islam), Nabi saw. bertanya kepada Muaz: "Dengan apakah engkau menetapkan hukum?" Jawabannya, "Dengan kitab Allah," kemudian Nabi bertanya: 
“Jika engkau tidak mendapatkan dalam kita Allah?" "Dengan sunnah Rasul," jawabnya lagi, Jika engkau juga tidak mendapatkan keterangan dalam sunnah Rasul?" tanya Rasul "Saya menggunakan akalku dan tidak berputus asa," kata Muaz. ${ }^{6}$

Kurikulum pendidikan moral al-Gazali didasarkan pada dua kecenderu-ngan yaitu, Pertama, kecederungan agama dan tasawuf. Kecenderungan ini membuat alGazali menempatkan ilmu-ilmu agama di atas segalanya, dan memandangnya sebagai alat untuk mensucikan diri dan membersihkan seseorang dari pengaruh kehidupan dunia. ${ }^{6}$ Dengan kecenderungan ini, al-Gazali sangat mementingkan pendidikan moral karena ilmu ini bertalian erat dengan pendidikan agama.

Kedua, kecenderungan pragmatis. Kecederungan ini tampak dalam karya tulisnya. Al-Gazali beberapa kali mengulang penilaiannya terhadap ilmu berdasarkan manfaatnya bagi manusia, baik untuk kehidupan di dunia, maupun kehidupan di akhirat. Ia juga menjelaskan bahwa ilmu netral/non syariat yang tidak dipergunakan pemiliknya pada hal-hal yang bermanfaat merupakan ilmu yang tak bernilai. ${ }^{7}$ Bagi alGazali, setiap ilmu harus dilihat dari segi fungsi dan kegunaannya dalam bentuk amaliah. Setiap amaliah yang disertai ilmu itu harus pula disertai dengan kesungguhan dan niat yang tulus ikhlas. Hal ini terlihat dalam ungkapannya berikut:

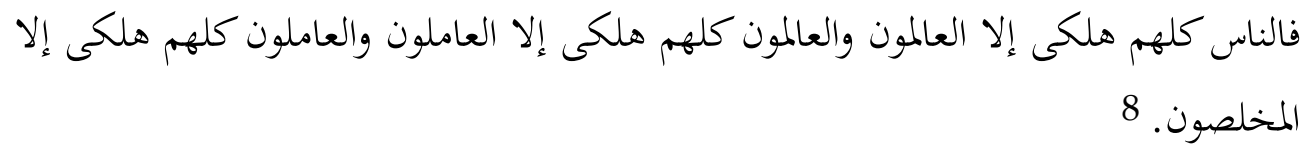

Artinya:

Seluruh manusia akan binasa kecuali yang berilmu, dan seluruh orang yang berilmu akan binasa kecuali yang beramal, dan seluruh orang yang beramal akan binasa kecuali orang yang ikhlas.

Dengan melihat sisi pemanfaatan dari suatu ilmu ini, al-Gazali tergolong sebagai penganut paham pragmatis teologis, yaitu pemanfaatan yang didasarkan atas tujuan keagamaan. Hal ini tidak dapat dilepaskan dari sikapnya sebagai seorang sufi yang memiliki tren praktis dan faktual. Adapun syarat pendidik moral bagi al-Gazali adalah sebagai uswatun hasanah. Pendidik dalam pendidikan merupakan komponen yang sangat menentukan keberlangsungan proses pembelajaran.

Berbeda dengan al-Gazali, konsep pendidikan moral yang diuraikan oleh Émile Durkheim lebih menekankan aspek pembentukan moralitas individu terhadap masyarakat. Émile Durkheim sebagaimana yang dikutip George Ritzer dan Douglas J. Goodman mendefinisikan pendidikan sebagai proses yang menekankan perolehan individu terhadap alat-alat fisik, intelektual, dan moral yang merupakan poin terpenting dalam pendidikan. Eksistensi moral bagi individu sangat diperlukan agar dapat berperan dalam masyarakat. ${ }^{9}$ Durkheim meyakini bahwa pendidikan merupakan sarana sosial untuk suatu tujuan sosial pada suatu masyarakat yang menjamin kelangsungan hidupnya. Pendidikan tidak hanya sekedar membantu mengembangkan individu sesuai dengan kodratnya, atau hanya membantu menyingkap segala 
kemampuan tersembunyi pada setiap individu,tetapi pendidikan juga mampu mencetak makhluk baru. ${ }^{10}$

Dengan demikian, pendidikan moral menurut Émile Durkheim bertu-juan untuk membentuk dan menciptakan makhluk baru (elle cree dans I homme un etre nouveau) yang memiliki rasa solidaritas dan disiplin yang tinggi untuk tujuan-tujuan sosial.

Adapun gagasan Émile Durkheim tentang pendidikan difokuskan pada pendidikan moral yang rasional, bukan pendidikan yang didasarkan pada agama dan wahyu. Secara ekslusif, pendidikan bersandar pada gagasan, senti-men, dan praktikpraktik berdasarkan perhitungan nalar semata. Dengan demikian, pendidikan rasional murni menjadi titik penekanannya. ${ }^{11}$ Bagi Dukheim, moralitas merupakan fakta sosial yang khas yang dalam semua bentuknya tidak dapat hidup kecuali dalam struktur masyarakat. ${ }^{12}$ Teori Durkheim tentang moral murni berlandaskan masyarakat. Bagi Durkheim, masyarakat adalah tujuan dari semua tindakan moral. Semua tindakan moral adalah suatu sistem aturan-aturan perilaku, tetapi tidak sebaliknya, semua aturan perilaku bersidat moral. ${ }^{13}$

Materi pendidikan moral menurut Émile Durkheim bukanlah suatu materi yang harus dicantumkan dalam kurikulum atau pengajar tertentu, akan tetapi hal ini merupakan kurikulum tersembunyi. Oleh karena itu, setiap guru harus memberikan contoh yang baik kepada peserta didik, baik dari aspek tingkah laku, pengetahuan, saling menghormati dan lain sebagainya. Di dalam sebuah instansi pendidikan, tanggung jawab pokok dalam pembentukan moral tidaklah terletak pada kegiatan intra kurikuler akan tetapi pada pengajar. Dalam hal ini, kurikulum Émile Durkheim berbasis sosioligis yang bersifat faktual. Adapun syarat pendidik moral menurut Émile Durkheim adalah sebagai profesinalisme dan seorang guru dituntut memiliki kompetensi yang tinggi karena seorang guru akan menjadi idola dalam manyarakat yang patut dicontoh.

Terkait metode pendidikan moral menurut Émile Durkheim sependa-pat dengan al-Gazali bahwa metode pendidikan moral yaitu kedisiplinan (pembiasaan), dan keteladanan. Namun, Émile Durkheim memasukkan meto-de hukuman dalam meningkatkan moralitas. Berbeda dengannya, al-Gazali mempunyai metode penyucian jiwa sebagai metode pendidikan moral.

Tabel 1 berikut disajikan untuk memberikan pemetaan bagaimana kedua tokoh ini berbicara secara diametral terkait hakikat moral, tujuan seseo-rang menjunjung tinggi moral, sumber moral, kurikulum yang mendukung pembelajaran materi moral, metode yang dipakai untuk mendidikan moral, dan syarat yang harus dipenuhi agar pendidikan moral menjadi apliktif dalam kehidupan.

Tabel 1: Manual Moral menurut al-Gazali dan Émile Durkheim

\begin{tabular}{|l|l|l|}
\hline ASPEK & \multicolumn{1}{|c|}{ Al Ghazali } & \multicolumn{1}{c|}{ Durkheim } \\
\hline Hakikat & $\begin{array}{l}\text { Pensucian jiwa } \\
\text { - Inner Capacity } \\
\text { - Leadership }\end{array}$ & $\bullet$ Social Capasity \\
\hline
\end{tabular}




\begin{tabular}{|c|l|l|}
\hline ASPEK & \multicolumn{1}{|c|}{ Al Ghazali } & \multicolumn{1}{c|}{ Durkheim } \\
\hline Tujuan & $\begin{array}{l}\bullet \text { Mendekatkan diri kepada } \\
\text { Tuhan } \\
\bullet \text { Kebahagiaan dunia } \\
\text { akhirat }\end{array}$ & $\begin{array}{l}\bullet \text { Membentuk kesadaran } \\
\text { kolektif } \\
\bullet \text { Membangun kesadaran } \\
\text { social }\end{array}$ \\
\hline Sumber & $\bullet$ Wahyu \\
& Agama & $\begin{array}{l}\bullet \text { Masyarakat } \\
\text { Budaya inti } \\
\bullet \text { Kearifan lokal }\end{array}$ \\
\hline Kurikulum & $\begin{array}{l}\bullet \text { Sosiologis yang berbasis } \\
\text { spiritual }\end{array}$ & $\begin{array}{l}\bullet \text { Sosiologis yang berbasis } \\
\text { factual }\end{array}$ \\
\hline Metode & $\begin{array}{l}\bullet \text { Tazkiyat } \\
\text { al-nafs } \\
\bullet \text { Keteladanan }\end{array}$ & $\begin{array}{l}\bullet \text { Disiplin } \\
\bullet \text { Keteladanan } \\
\bullet \text { Hukuman }\end{array}$ \\
\hline Syarat & $\bullet$ Uswah Hasanah & $\bullet$ Profesionalisme \\
& & Kompetensi \\
\hline
\end{tabular}

Analisis Kritis terhadap Konsep Pendidikan Moral menurut al-Gazali dan Émile Durkheim dan Relevansinya dengan Konsep Pendidikan Islam.

Gagasan pendidikan moral menurut al-Gazali dan Émile Durkheim sejalan dengan konsep pendidikan Islam. Konsep pendidikan Islam merangkul gagasan kedua tokoh tersebut dengan mendudukkan pendidikan sebagai bagian yang tidak terpisahkan dari prinsip pengembangan moral baik individu maupun masyarakat. Relevansi pendidikan Islam dengan sumber pendidikan pendidikan moral yang diungkapkan oleh kedua tokoh tersebut dapat dilihat pada prinsip pendidikan Islam yaitu bersifat universal dan menyeluruh, yaitu antara ilmu empirik, sosial, dan wahyu saling berkaitan, dan ketiga ilmu tersebut berasal dari Allah.

Meskipun kedua tokoh tersebut menggunakan pendekatan yang berbeda dalam memandang atau menilai moralitas. Moralitas dalam perspektif pendidikan Islam memandang harus menggunakan pendekatan yang melibatkan seluruh aspek dan potensi manusia. Hal tersebut tercermin pada prinsip pendidikan Islam yaitu prinsip universal dan prinsip keseimbangan.

Pendidikan Islam juga mengungkapkan peranan lembaga pendidikan (sekolah) untuk membantu individu menum-buhkan dan membentuk moralitasnya. Melalui pendidikan formal, umat manusia akan mencapai perada-ban dan memiliki kecerdasan intelektual, emosional, dan spiritual yang tinggi sebagai bekal untuk melanjutkan dan memperjuangkan agamanya. Oleh karena itu, bukan sebuah kekeliruan ketika al-Gazali dan Émile Durkheim menjadikan sekolah sebagai wadah bagi peserta didik untuk mengembangkan moralitasnya. 


\section{Integrasi Paradigma al-Gazali dan Émile Durkheim dalam Pengembangan Pendi- dikan Moral}

Gambar 1: Pola Integrasi Paradigma al-Gazali dan Durkheim

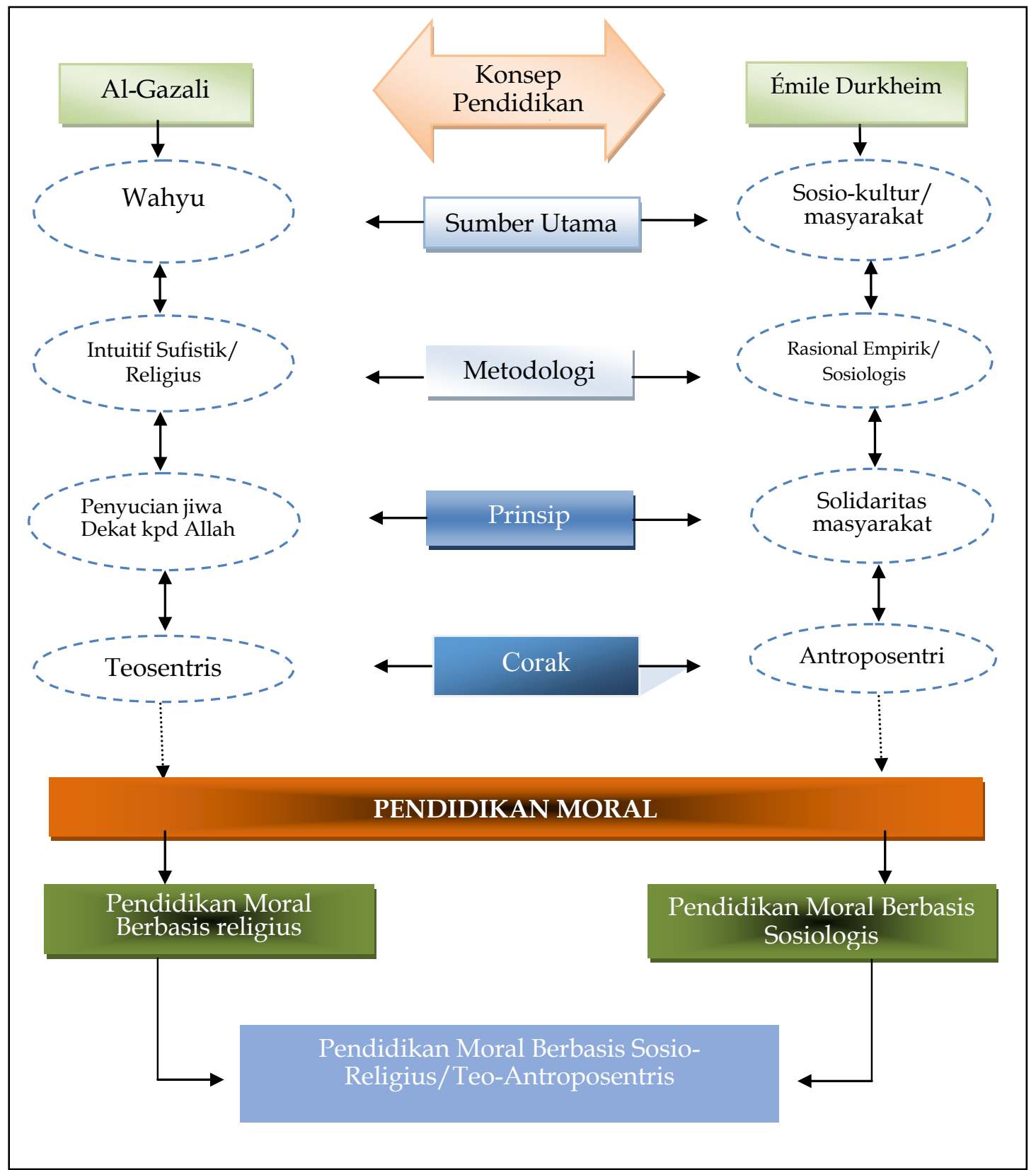

Integrasi paradigma al-Gazali dan Émile Durkheim dalam pengembangan konsep pendidikan moral akan melahirkan paradigma baru pendidikan moral yaitu "pendidikan moral berbasis sosio-religius", sebuah konsep pendidikan moral yang hendak memadukan antara dimensi spiritual dengan dimensi realitas empirik. Paradigma pendidikan moral yang berbasis sosio-religius adalah paradigma yang mampu mengintegrasikan seluruh aspek kehidupan yang religius yang mencakup jasmani, 
rohani, intelektual, dan moral. Pendidkan moral harus mampu megintegrasikan aspek-aspek spiritual maupun intelektual serta aspek normativitas dan historitas (realitas). Integrasi keseluruhan aspek tersebut akan menjadi inti bagi keseimbangan aspek kognitif (akal), afektif (iman), dan psikomotorik (amal) dalam pendidikan secara praktis.

\section{SIMPULAN}

Paradigma al-Gazali dan Emile Durkheim tentang pendidikan moral dapat dijadikan sebagai bahan dekonstruksi terhadap konstruksi paradigma pendidikan moral yang dianggap sudah mapan sehingga melahirkan paradigma integratif yang mengapresiasi dan mempertautkan serta memper-temukan tradisi keilmuan Barat dan Timur sebagai upaya pengembangan konsep pendidikan moral dan keilmuan secara umum. Penelitian ini juga diharap dapat menjadi bagian dari tangga pencarian wajah baru pendidikan moral yang relevan dengan konteks keindonesiaan.

\section{CATATAN AKHIR}

1. Alienasi adalah kondisi terasing, terisolasi: ketidakseimbangan antara sukses duaniawi dan sukses batiniah, membuat manusia tidak memiliki kesimbangan antara dunia dan akhirat.

2. Muhammad Tholhah Hasan, Prospek Islam dalam Menghadapi Tantangan Masyarakat, cet. VI; Jakarta: Lantabora Press, 2005, h. 72.

3. Zainuddin Abu Hamid Muhammad bin Muhammad al-Tusial-Gazali, Ihy ya' 'Ulum al-Din, Jilid IV, Kairo: al-Sya'b, t.th., h. 599.

4. Fuad Mahbub Siraj, Al-Gazali Pembela Sejati Kemurnian Islam, cet. I; Jakarta: Dian Rakyat, 2012, h. 80.

5. Amin Abdullah, Filsafat Etika Islam: Antara Al-Gazali dan Kant, cet. II; Bandung: Mizan, 2002, h. 11.

6. Abu Daud Sulaiman bin al-Asy'asy al-Sajastani al-Azdi, Sunan Abi Daud, Kitab alAqdjiyah fi al-S\}ulh Bab Ijtihad al-Ra'yi fi al-Qada', Jilid II, Beirut: Dar al-Fikr, 1994, h. 168 .

7. Zainuddin Abu Hamid Muhammad bin Muhammad al-Tusial-Gazali, Ihyya' 'Ulum al-Din, Jilid IV, Kairo: al-Sya'b, t.th., h.86.

8. Ibid., h. 2684.

9. Ibid.

10. George Ritzer \& Douglas J. Goodman, Sociological Theory, Mcgraw-Hill: New York, 2004, h. 115.

11. Émile Durkheim, Moral Education, terj. Lukas Ginting, Pendidikan Moral, Jakarta: Erlangga, 1990, h. xii-xiii.

12. Ibid., h. 2.

13. Djuretna A. Imam Muhni, Moral \& Religi: Menurut Émile Durkheim dan Hendri Bergson, cet. I; Yogyakarta: Kanisius, 1994, h. 39.

14. L. Lacyendecker, Tata, Perubahan, dan Ketimpangan Sosial: Suatu Pengantar Sejarah Sosial, cet. II; Jakarta: Gramedia Pustaka Utama, 1983, h. 299. 


\section{DAFTAR PUSTAKA}

Abdullah, Amin. Filsafat Etika Islam: Antara Al-Gazali dan Kant. Cet. II; Bandung: Mizan, 2002.

Abu Daud, Sulaiman bin al-Asy'asy al-Sajastani al-Azdi. Sunan Abi Daud, Kitab alAqdiyah fi al-Sulh Bab Ijtihad al-Ra' yi fi al-Qada'. Jilid II, Beirut: Dar al-Fikr, 1994.

Durkheim, Émile. Moral Education terj. Lukas Ginting, Pendidikan Moral. Jakarta: Erlangga, 1990.

AL-Gazali, Zainuddin Abu Hamid Muhammad bin Muhammad al-Tusi. Ihya' 'Ulum al-Din. Jilid IV, Kairo: al-Sya'b, t.th.

Hasan, Muhammad Tholhah. Prospek Islam dalam Menghadapi Tantangan Masyarakat. Cet. VI; Jakarta: Lantabora Press, 2005.

Lacyendecker, L. Tata, Perubahan, dan Ketimpangan Sosial: Suatu Pengantar Sejarah Sosial. Cet. II; Jakarta: Gramedia Pustaka Utama, 1983.

Muhni, Djuretna A. Imam. Moral \& Religi: Menurut Émile Durkheim dan Hendri Bergson Cet. I; Yogyakarta: Kanisius, 1994.

Ritzer, George \& Douglas J. Goodman. Sociological Theory. Mcgraw-Hill: New York, 2004.

Siraj, Fuad Mahbub. Al-Gazali Pembela Sejati Kemurnian Islam. Cet. I; Jakarta: Dian Rakyat, 2012. 